\title{
BRIEFING PAPER
}

Number SN04423, 17 June 2015

\section{Research and Development in the UK}

By Richard Keen

1. Background to R\&D statistics

2. Gross Domestic Expenditure on R\&D in the UK

3. Government expenditure on R\&D by departments 


\section{Contents}

Summary

3

1. Background to R\&D statistics

4

1.1 The definition of R\&D

1.2 Gross Domestic Expenditure on R\&D (GERD)

1.3 Funding Sectors

1.4 Performing sectors

2. Gross Domestic Expenditure on R\&D in the UK

2.1 Expenditure by region

2.2 Expenditure in the Business Sector

3. Government expenditure on R\&D by departments 


\section{Summary}

Two main data series provide statistics on research and development in the UK.

The ONS's gross domestic expenditure on R\&D (GERD) series provides gross expenditure for R\&D performed specifically within the UK.

The Science, Engineering and Technology (SET) series, alternatively, provides net figures for government spending including net contributions to EU programmes.

In 2013 gross domestic expenditure on R\&D (GERD) in the UK was $f 28.9$ billion, or $1.67 \%$ of GDP.

Between 1985 and 2013 GERD grew by 52\% in real terms, but because it has not grown as fast as the economy as a whole it has fallen as a proportion of GDP from $2.01 \%$ to $1.67 \%$.

The South East, East of England and London account for a combined 52\% of R\&D performed in the UK. Other areas with large shares of R\&D include the North West $(8.7 \%)$, the South West $(7.7 \%)$ and Scotland $(7.2 \%)$.

Business enterprise performed £18.4 billion (64\%) of UK GERD in 2013.

Pharmaceuticals comprised $22 \%$ of this total, motor vehicles and parts $11 \%$, computer programming and information services $11 \%$ and aerospace $9 \%$.

Net government expenditure on R\&D was $f 9.7$ billion in 2012, according to the ONS's SET statistics. This is a $13.5 \%$ rise, in real terms, on expenditure a decade previously.

Net expenditure comprised of $\mathrm{f} 3.0$ billion (31\%) to research councils, $\mathrm{f2.2}$ billion ( $23 \%$ ) to higher education funding councils, $\mathrm{f2.3}$ billion (24\%) to civil departments and $£ 1.5$ billion (15\%) to the Ministry of Defence. 


\section{Background to R\&D statistics}

Statistics showing public and private expenditure on research and development $(R \& D)$ in the UK are published by the Office for National Statistics (ONS) in their annual statistical releases on Gross Domestic Expenditure on Research and Development, and their annual UK Government Expenditure on Science, Engineering and Technology series. This series, known as SET statistics, was previously published by the Department for Business, Innovation and Skills.

The concepts and definitions used to measure R\&D in the UK are set out in the OECD's Frascati Manual, which establishes a common basis for measuring R\&D activity in different countries. Understanding R\&D statistics means understanding these definitions and the activities they encapsulate.

\subsection{The definition of R\&D}

The OECD defines R\&D in the following way:

Research and experimental development (R\&D) comprise creative work undertaken on a systematic basis in order to increase the stock of knowledge, including knowledge of man, culture and society, and the use of this stock of knowledge to devise new applications. ${ }^{1}$

$R \& D$ is distinguished from other scientific and technological activities related to the circulation and dissemination of knowledge by excluding activities that do not involve the production of new knowledge directed at solving specific problems:

The basic criterion for distinguishing R\&D from related activities is the presence in R\&D of an appreciable element of novelty and the resolution of scientific and/or technological uncertainty, i.e. when the solution to a problem is not readily apparent to someone familiar with the basic stock of common knowledge and techniques for the area concerned. ${ }^{2}$

This definition of R\&D therefore excludes things like education, training, bibliographic and referencing work, routine technological development (e.g. the deployment of software systems that are already well understood) and the management of existing knowledge and data. 


\subsection{Gross Domestic Expenditure on R\&D (GERD)}

The total expenditure on R\&D carried out within a given country is referred to as gross domestic expenditure on R\&D, or GERD. It is defined in the following way:

GERD is total intramural expenditure on R\&D performed on the national territory during a given period. ${ }^{3}$

Here, the word "intramural" means expenditure carried out by the research-performing units in a given country, irrespective of their source of funding. As the Frascati manual explains:

GERD includes R\&D performed within a country and funded from abroad but excludes payments for R\&D performed abroad. $^{3}$

GERD is therefore measured by adding up the expenditure of individual research units. It measures expenditure by the units performing the research (firms, institutes, universities etc.) not the organisations funding it. Nevertheless, once GERD in a given country has been quantified in this way, it is possible to identify the sources of funding for that activity. GERD can therefore be broken down either by the funding or the performing sectors.

\subsection{Funding Sectors}

GERD is typically divided into five research funding sectors:

- Business enterprise

- Government

- Higher Education

- Private non-profit (PNP)

- Abroad

In the UK, the ONS also lists Research Councils and Higher Education Funding Councils as separate research funding categories. These categories are included in the Government sector in international comparisons.

\subsection{Performing sectors}

GERD is typically divided into four research performing sectors:

- Business enterprise

- Government

- Higher Education

- Private non-profit (PNP)

In the UK, the ONS also lists Research Councils as a separate research performing category. This category is included in the Government sector in international comparisons.

$3 \quad$ ibid., page 121 


\section{Gross Domestic Expenditure on $R \& D$ in the UK}

In 2013, gross domestic expenditure on R\&D in the UK was $f 28.9$

billion, or $1.67 \%$ of GDP. Between 1985 and 2013 GERD grew by 52\% in real terms, but because it has not grown as fast as the economy as a whole it has fallen as a proportion of GDP from $2.01 \%$ to $1.67 \%$.

\section{Chart 1 GERD as a percentage of GDP, UK, 1985-2013}

$\%$, current prices

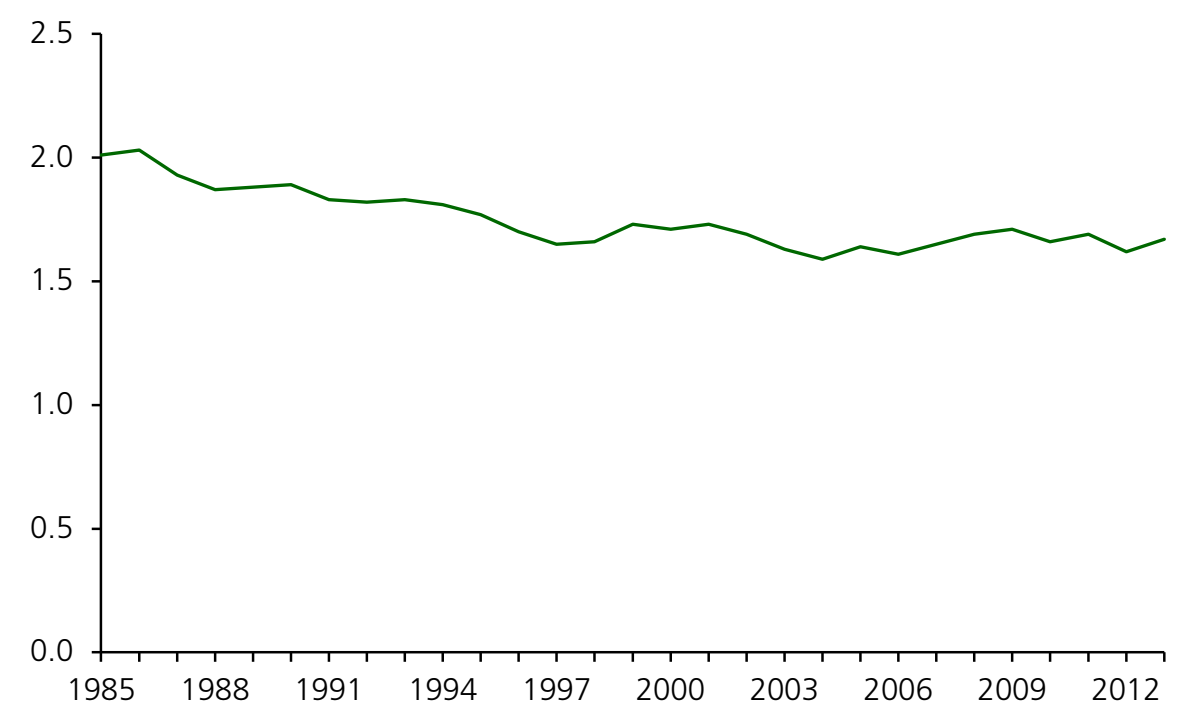

Source: Gross Domestic Expenditure on Research and Development, 2013

Chart 2 shows a breakdown of GERD by funding sector from 1985 to 2013. During this period, the fastest growing sector of funding for R\&D performed in the UK was funding from abroad, which grew by $251 \%$ in real terms. Funding from higher education also grew in real terms, by $199 \%$, but from a very much smaller base. Funding from business enterprise grew by $52 \%$ in real terms. Total government funding (including Research Councils and Higher Education Councils) in 2013 was $£ 8.4$ billion, having peaked at $\mathrm{f9.0}$ billion in 2009 .

In 2013, business enterprise was the largest sector of funding for R\&D, accounting for $46 \%$ of all funding for R\&D performed in the UK, worth f13.3 billion. The government sector (including Research Councils and Higher Education Funding Councils) funded around 29\% ( $f 8.4$ billion) of $R \& D$ performed in the UK; while funding from abroad accounted for $19 \%$ ( $₫ 5.4$ billion). 


\section{Chart 2 Real terms GERD by sector of funding, United Kingdom, 1985-2013}

f billion, 2013 prices

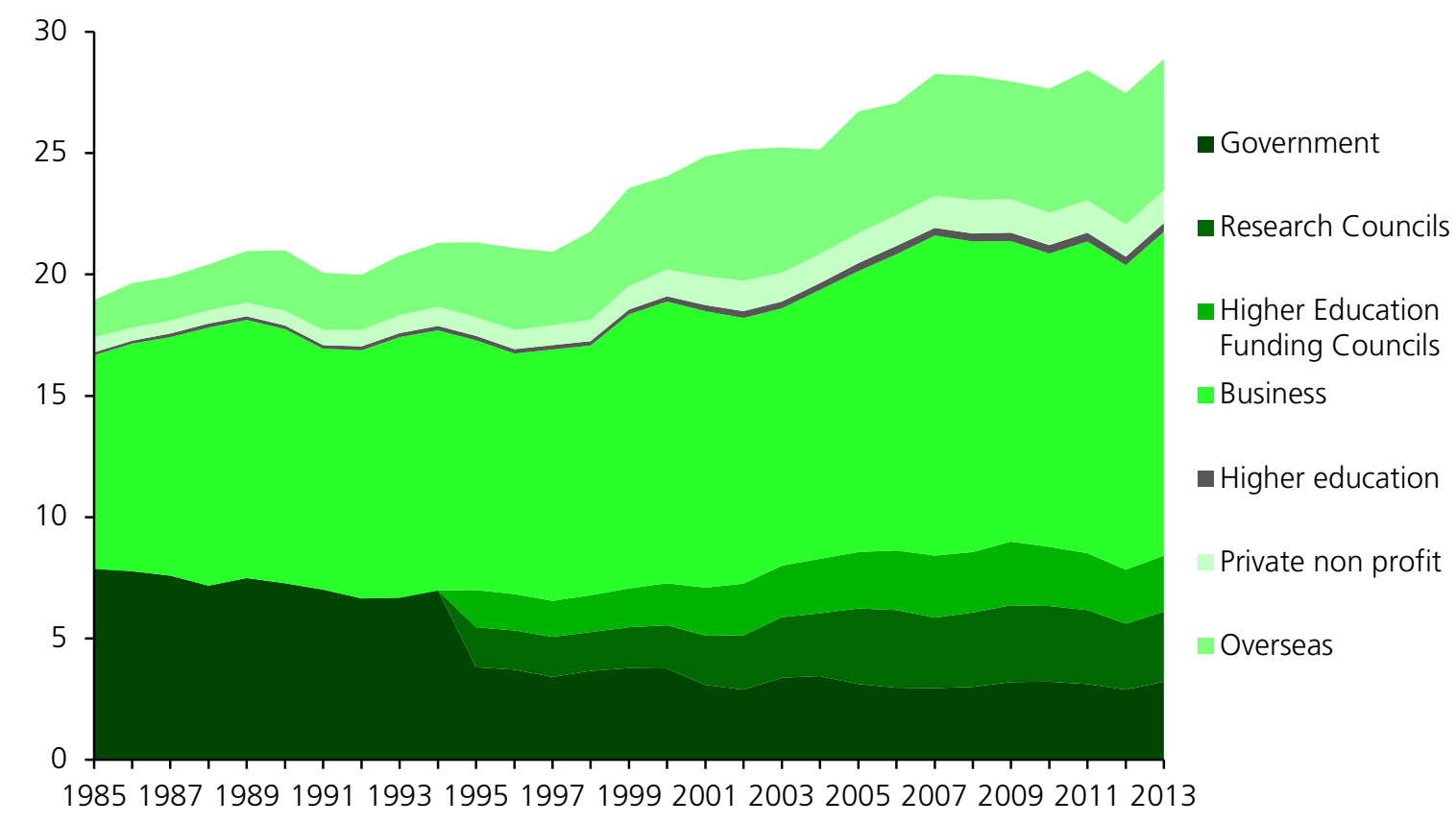

Source: ONS, UK Gross Domestic Expenditure on Research and Development historical data

Chart 3 shows a breakdown of GERD by performing sector from 1985 to 2013. Business enterprise was the largest R\&D performing sector during the period, accounting for $64 \%$ of R\&D performed in the UK in both 1985 and 2013. In 2013, expenditure on research performed in the business enterprise sector was $₫ 18.4$ billion. Higher education's share of performance increased from 15\% in 1985 to $26 \%$ in 2013.

\section{Chart 3 Real terms GERD by sector of performance, United Kingdom, 1985-2013}

f billion, 2013 prices

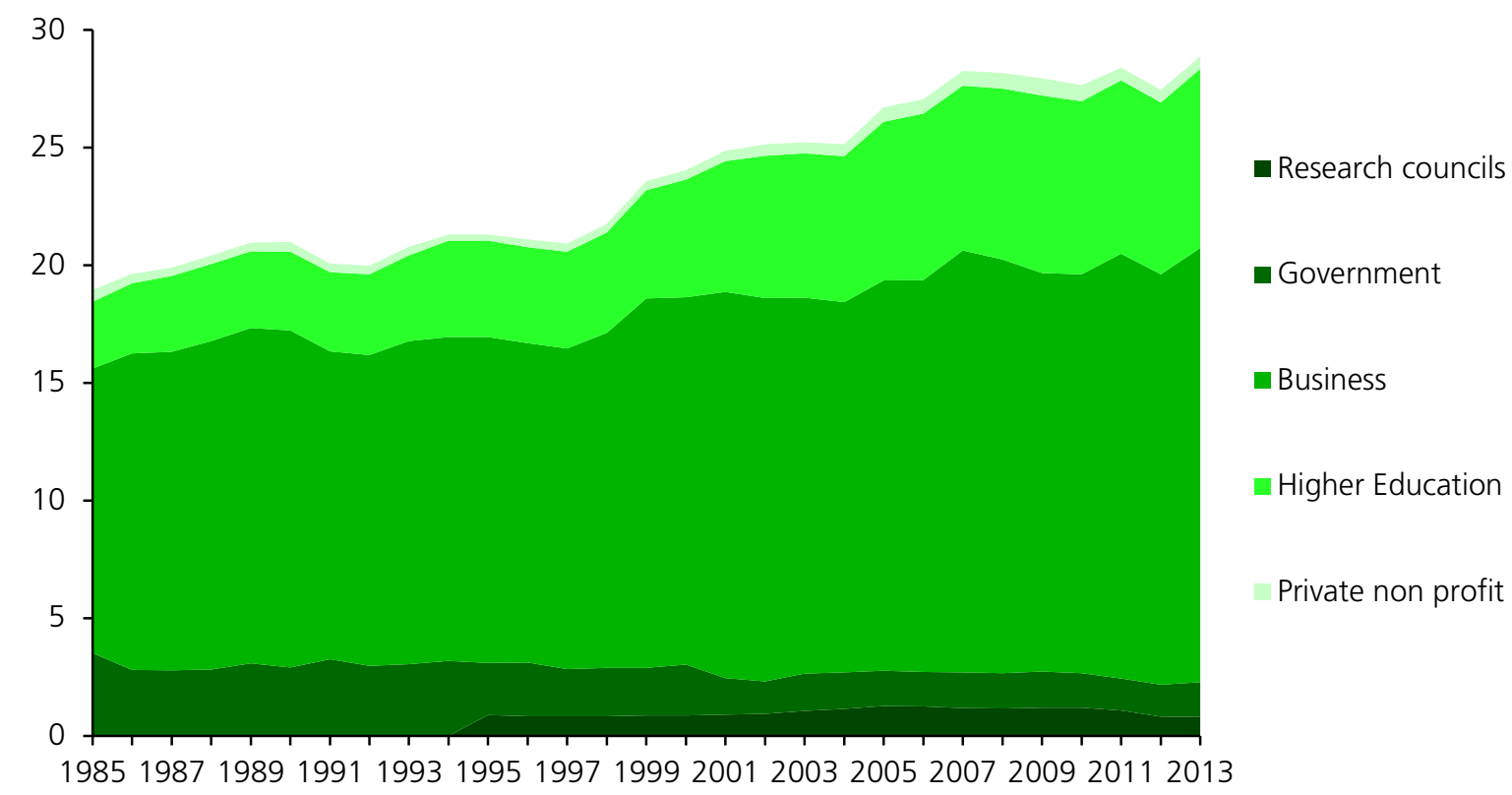

Source: ONS, ONS, UK Gross Domestic Expenditure on Research and Development historical data 
Table 1 shows the relationship between the sectors funding and performing R\&D carried out in the UK in 2013. This shows the relationship between the sources and destination of funding in the most recent year.

Table 1: R\&D performed in the UK in each sector according to source of funding, 2013

Current prices, $\mathrm{f}$ millions $\quad$ Sector performing the R\&D

\begin{tabular}{|c|c|c|c|c|c|c|c|}
\hline & Government & $\begin{array}{l}\text { Research } \\
\text { Councils }\end{array}$ & $\begin{array}{r}\text { Higher } \\
\text { Education }\end{array}$ & $\begin{array}{r}\text { Business } \\
\text { Enterprise }\end{array}$ & $\begin{array}{r}\text { Private } \\
\text { Non-Profit }^{1}\end{array}$ & Total & Overseas \\
\hline \multicolumn{8}{|l|}{ Sector providing the funds } \\
\hline Government & 1,050 & 77 & 380 & 1,646 & 61 & 3,214 & 547 \\
\hline Research Councils & 60 & 600 & 2,121 & 3 & 115 & 2,899 & 200 \\
\hline Higher Education Funding Councils & - & - & 2,297 & - & - & 2,297 & - \\
\hline Higher Education & 1 & 13 & 300 & - & 54 & 368 & - \\
\hline Business Enterprise & 239 & 25 & 313 & 12,750 & 16 & 13,343 & 3,305 \\
\hline Private Non-Profit & 5 & 48 & 1,051 & 74 & 185 & 1,362 & - \\
\hline Overseas & 112 & 51 & 1,167 & 3,975 & 87 & 5,393 & - \\
\hline TOTAL & 1,467 & 813 & 7,628 & 18,448 & 518 & 28,875 & - \\
\hline \multicolumn{8}{|l|}{ of which: } \\
\hline Civil & 1,303 & 813 & 7,592 & 16,734 & 516 & 26,959 & - \\
\hline Defence $^{1}$ & 164 & - & 37 & 1,713 & 2 & 1,916 & - \\
\hline
\end{tabular}

1 Private Non-Profit defence has been estimated using the 2012 data, as no survey data available for 2013.

- denotes nil, figures unavailable or too small to display.

Source: Gross Domestic Expenditure on Research and Development, 2013

\subsection{Expenditure by region}

Table 2 shows a breakdown of GERD by region and performing sector in 2013. The first section of the table shows the value of expenditure on $R \& D$ performed in each region, while the second section shows the percentage of expenditure on R\&D performed in each region.

The South East, East of England, and London accounted for a combined $52 \%$ of R\&D performed in the UK. Other areas with large shares of R\&D were the North West (8.7\%), the South West $(7.7 \%)$ and Scotland $(7.2 \%)$. 


\section{Table 2: R\&D performed in the UK by region and sector of performance, 2013}

f million - current prices

\begin{tabular}{|c|c|c|c|c|c|}
\hline & Government ${ }^{1,5}$ & $\begin{array}{r}\text { Higher } \\
\text { Education }^{2} \\
\end{array}$ & Business $^{3}$ & $\begin{array}{r}\text { Private } \\
\text { Non-Profit }{ }^{4,5} \\
\end{array}$ & Total \\
\hline United Kingdom & 2,281 & 7,628 & 18,448 & 518 & 28,875 \\
\hline England & 2,002 & 6,153 & 16,838 & 509 & 25,502 \\
\hline Wales & 33 & 284 & 369 & 1 & 687 \\
\hline Scotland & 223 & 1,041 & 798 & 8 & 2,070 \\
\hline Northern Ireland & 23 & 150 & 443 & - & 616 \\
\hline \multicolumn{6}{|l|}{ Regions of England } \\
\hline North East ${ }^{5}$ & .. & 250 & 309 & .. & 576 \\
\hline North West ${ }^{5}$ & .. & 600 & 1,784 & .. & 2,509 \\
\hline North East and North West ${ }^{5}$ & 85 & 850 & 2,093 & 57 & 3,085 \\
\hline Yorkshire and the Humber & 74 & 531 & 644 & 4 & 1,253 \\
\hline East Midlands & 87 & 338 & 1,369 & 2 & 1,796 \\
\hline West Midlands & 4 & 371 & 1,697 & - & 2,072 \\
\hline East of England & 212 & 699 & 4,071 & 260 & 5,242 \\
\hline London & 335 & 1,874 & 1,317 & 148 & 3,674 \\
\hline South East & 847 & 1,105 & 4,195 & 21 & 6,168 \\
\hline South West & 358 & 385 & 1,452 & 17 & 2,212 \\
\hline
\end{tabular}

Expenditure by sector and region as a percetnage of UK expenditure

\begin{tabular}{|c|c|c|c|c|c|}
\hline & \multirow[b]{2}{*}{ Government $^{1,5}$} & \multicolumn{2}{|l|}{ Higher } & \multicolumn{2}{|l|}{ Private } \\
\hline & & Education $^{2}$ & Business $^{3}$ & Non-Profit ${ }^{4,5}$ & Total \\
\hline England & $87.8 \%$ & $80.7 \%$ & $91.3 \%$ & $98.3 \%$ & $88.3 \%$ \\
\hline Wales & $1.4 \%$ & $3.7 \%$ & $2.0 \%$ & $0.2 \%$ & $2.4 \%$ \\
\hline Scotland & $9.8 \%$ & $13.6 \%$ & $4.3 \%$ & $1.5 \%$ & $7.2 \%$ \\
\hline Northern Ireland & $1.0 \%$ & $2.0 \%$ & $2.4 \%$ & & $2.1 \%$ \\
\hline \multicolumn{6}{|l|}{ Regions of England } \\
\hline North East ${ }^{5}$ & & $3.3 \%$ & $1.7 \%$ & & $2.0 \%$ \\
\hline North West ${ }^{5}$ & & $7.9 \%$ & $9.7 \%$ & & $8.7 \%$ \\
\hline North East and North West ${ }^{5}$ & $3.7 \%$ & $11.1 \%$ & $11.3 \%$ & $11.0 \%$ & $10.7 \%$ \\
\hline Yorkshire and the Humber & $3.2 \%$ & $7.0 \%$ & $3.5 \%$ & $0.8 \%$ & $4.3 \%$ \\
\hline East Midlands & $3.8 \%$ & $4.4 \%$ & $7.4 \%$ & $0.4 \%$ & $6.2 \%$ \\
\hline West Midlands & $0.2 \%$ & $4.9 \%$ & $9.2 \%$ & & $7.2 \%$ \\
\hline East of England & $9.3 \%$ & $9.2 \%$ & $22.1 \%$ & $50.2 \%$ & $18.2 \%$ \\
\hline London & $14.7 \%$ & $24.6 \%$ & $7.1 \%$ & $28.6 \%$ & $12.7 \%$ \\
\hline South East & $37.1 \%$ & $14.5 \%$ & $22.7 \%$ & $4.1 \%$ & $21.4 \%$ \\
\hline South West & $15.7 \%$ & $5.0 \%$ & $7.9 \%$ & $3.3 \%$ & $7.7 \%$ \\
\hline
\end{tabular}

1 Government figures include Research Councils and estimates for those areas of Central Government not available from the Government Survey or from local authorities.

2 Higher Education regional data estimates provided by HEFCE.

3 Business regional estimates first published in the BERD publication on 20 November 2014.

4 Private Non-Profit estimates have been published using the 2013 survey data from the bienniel survey.

5 North East and North West regions data have been combined due to confidentiality.

- denotes nil, figures unavailable or too small to display.

.. denotes disclosive figures. 


\subsection{Expenditure in the Business Sector}

Table 3 shows the percentage of expenditure on R\&D performed in the UK business enterprise sector by the highest performing industries in 2013. Pharmaceuticals accounted for $22 \%$ of business enterprise R\&D in 2013, with motor vehicles and parts (11\%), computer programming and information services (11\%) and aerospace (9\%) also accounting for large shares of business enterprise $R \& D$.

Table 3 R\&D performed in the UK business sector, 2013

\begin{tabular}{lrr} 
& $f$ billion & $\%$ \\
\hline & & \\
Pharmaceuticals & 4.1 & 22.1 \\
Motor vehicles and parts & 2.1 & 11.2 \\
Computer programming and information service activities & 2.0 & 10.9 \\
Aerospace & 1.7 & 9.0 \\
Machinery and equipment & 1.0 & 5.6 \\
Miscellaneous business activities; Technical testing and analysis & 1.0 & 5.3 \\
Telecommunications & 0.8 & 4.6 \\
Consumer electronics and communication equipment & 0.8 & 4.5 \\
Precision instruments and optical products; Photographic equipment & 0.6 & 3.2 \\
Other & 4.3 & 23.6 \\
Total & & \\
\hline
\end{tabular}

Source: Gross Domestic Expenditure on Research and Development, 2013

The ONS's Business Enterprise Research and Development bulletins provide further analysis of these figures. 


\section{Government expenditure on R\&D by departments}

Table 4 shows net government expenditure on R\&D in 2012 broken down into the various research performing departments, including research councils, higher education funding councils, and civil and military government departments. Table $\mathbf{5}$ provides a broad departmental breakdown of this funding in each year from 2001 to 2012.

These figures are taken from ONS statistics on SET rather than GERD. There are several differences between the two datasets. First, net expenditure on R\&D is different to gross expenditure: it is equal to gross expenditure on $R \& D$ less any funding received for $R \& D$. Second, SET statistics include the UK's net contribution to European Union R\&D programmes. This contribution is typically excluded from GERD because it does not reflect research performed within the UK. Finally, SET statistics are for financial years, while ONS GERD statistics are for calendar years. These differences lead to small differences between government-funded GERD in ONS statistics and net government expenditure on R\&D in BIS statistics. Nevertheless, SET statistics offer the most detailed breakdown of government funding for R\&D. 
Table 4 Net Government expenditure on R\&D by departments 2012

\begin{tabular}{|c|c|c|}
\hline & $\begin{array}{c}\text { Current Pric } \\
\mathrm{f} \text { million } \\
\end{array}$ & $\frac{E \text { million }}{\%}$ \\
\hline \multicolumn{3}{|l|}{ Research Councils: } \\
\hline Engineering and Physical Sciences (EPSRC) & 793 & $8.2 \%$ \\
\hline Medical (MRC) & 600 & $6.2 \%$ \\
\hline Biotechnology and Biological Sciences (BBSRC) & 478 & $4.9 \%$ \\
\hline Science and Technology Facilities (STFC) & 456 & $4.7 \%$ \\
\hline Natural Environment (NERC) & 378 & $3.9 \%$ \\
\hline Economic and Social (ESRC) & 179 & $1.9 \%$ \\
\hline Arts and Humanities (AHRC) & 90 & $0.9 \%$ \\
\hline Pensions & 37 & $0.4 \%$ \\
\hline TOTAL & 3,010 & $31.1 \%$ \\
\hline \multicolumn{3}{|l|}{ Higher Education Funding Councils (HEFCs): } \\
\hline England (HEFCE) & 1,736 & $18.0 \%$ \\
\hline Scotland (SFC) & 312 & $3.2 \%$ \\
\hline Northern Ireland (DELNI) & 57 & $0.6 \%$ \\
\hline Wales (HEFCW) & 80 & $0.8 \%$ \\
\hline TOTAL & 2,185 & $22.6 \%$ \\
\hline \multicolumn{3}{|l|}{ Civil Departments: } \\
\hline Health (DH including NHS) & 924 & $9.6 \%$ \\
\hline of which: National Health Service (NHS) & 892 & $9.2 \%$ \\
\hline Business, Innovation and Skills (BIS) & 729 & $7.5 \%$ \\
\hline International Development (DFID) & 229 & $2.4 \%$ \\
\hline Scottish Government (SG) & 164 & $1.7 \%$ \\
\hline Environment, Food and Rural Affairs (DEFRA) & 141 & $1.5 \%$ \\
\hline Culture, Media and Sport (DCMS) & 45 & $0.5 \%$ \\
\hline Transport (DfT) & 38 & $0.4 \%$ \\
\hline Energy and Climate Change (DECC) & 37 & $0.4 \%$ \\
\hline Welsh Government (WG) & 11 & $0.1 \%$ \\
\hline Other Departments & 26 & $0.3 \%$ \\
\hline Northern Ireland Departments (NI) & 21 & $0.2 \%$ \\
\hline Work and Pensions (DWP) & 21 & $0.2 \%$ \\
\hline Home Office (HO) & 18 & $0.2 \%$ \\
\hline Education (DfE) & 14 & $0.1 \%$ \\
\hline Communities and Local Government (DCLG) & 9 & $0.1 \%$ \\
\hline Ministry of Justice (MoJ) & 8 & $0.1 \%$ \\
\hline Health and Safety Executive (HSE) & 8 & $0.1 \%$ \\
\hline Food Standards Agency (FSA) & 7 & $0.1 \%$ \\
\hline Foreign and Commonwealth Office (FCO) & $\sim$ & $\sim$ \\
\hline Net Launch Investment & -150 & $-1.6 \%$ \\
\hline TOTAL & 2,298 & $23.8 \%$ \\
\hline \multicolumn{3}{|l|}{ Ministry of Defence (MoD) } \\
\hline \multirow{2}{*}{$\begin{array}{l}\text { Research } \\
\text { Development }\end{array}$} & 565 & $5.8 \%$ \\
\hline & 895 & $9.3 \%$ \\
\hline TOTAL & 1,460 & $15.1 \%$ \\
\hline Indicative UK contributions to EU R\&D expenditure & 718 & $7.4 \%$ \\
\hline GRAND R\&D TOTAL & 9,671 & $100.0 \%$ \\
\hline
\end{tabular}

denotes value too small to display.

Notes: 1. "Other departments" includes: HMRC, HMT, Forestry Commission, Ordnance Survey Research, GCHQ, Ofsted and OFFA. 2. Figures for the departments may not add up to the grand total shown due to rounding. 3. See Table 3 of ONS SET statistics for detailed footnotes. Source: ONS, Science, engineering and technology statistics 2012, Table 3 
Table 5: Net Government expenditure on R\&D by departments, 2012

\begin{tabular}{|c|c|c|c|c|c|c|c|c|c|c|c|c|}
\hline \multicolumn{13}{|c|}{ £ million - current prices } \\
\hline & 2001 & 2002 & 2003 & 2004 & 2005 & 2006 & 2007 & 2008 & 2009 & 2010 & 2011 & 2012 \\
\hline Civil & 5,109 & 5,785 & 6,127 & 6,076 & 6,777 & 6,994 & 7,060 & 7,709 & 8,287 & 8,215 & 8,357 & 8,211 \\
\hline Research Councils: & 1,649 & 1,870 & 2,143 & 2,281 & 2,763 & 2,883 & 2,714 & 2,984 & 3,148 & 3,201 & 3,194 & 3,010 \\
\hline Higher Education Funding Councils (HEFCs) & 1,474 & 1,626 & 1,665 & 1,804 & 1,928 & 2,085 & 2,234 & 2,227 & 2,395 & 2,303 & 2,257 & 2,185 \\
\hline Civil Departments: & 1,595 & 1,849 & 1,929 & 1,666 & 1,721 & 1,652 & 1,738 & 1,905 & 2,076 & 2,064 & 2,245 & 2,298 \\
\hline Indicative UK contributions to EU R\&D expenditure & 391 & 440 & 390 & 325 & 365 & 374 & 374 & 593 & 668 & 647 & 661 & 718 \\
\hline Ministry of Defence & 2,057 & 2,734 & 2,133 & 2,191 & 2,243 & 2,124 & 2,139 & 1,991 & 1,752 & 1,693 & 1,306 & 1,460 \\
\hline Research & 557 & 516 & 524 & 639 & 598 & 632 & 635 & 584 & 575 & 534 & 553 & 565 \\
\hline Development & 1,500 & 2,218 & 1,609 & 1,552 & 1,645 & 1,492 & 1,505 & 1,406 & 1,177 & 1,159 & 753 & 895 \\
\hline \multirow[t]{3}{*}{ Total } & 7,165 & 8,519 & 8,260 & 8,267 & 9,021 & 9,119 & 9,199 & 9,699 & 10,039 & 9,907 & 9,664 & 9,671 \\
\hline & & & & & & & & & & \multicolumn{3}{|c|}{ E million - constant prices } \\
\hline & 2001 & 2002 & 2003 & 2004 & 2005 & 2006 & 2007 & 2008 & 2009 & 2010 & 2011 & 2012 \\
\hline Civil & 6,636 & 7,345 & 7,633 & 7,365 & 8,068 & 8,095 & 7,969 & 8,464 & 8,856 & 8,553 & 8,506 & 8,211 \\
\hline Research Councils: & 2,142 & 2,374 & 2,670 & 2,765 & 3,289 & 3,337 & 3,063 & 3,276 & 3,364 & 3,333 & 3,251 & 3,010 \\
\hline Higher Education Funding Councils (HEFCs) & 1,915 & 2,065 & 2,074 & 2,187 & 2,296 & 2,413 & 2,522 & 2,445 & 2,559 & 2,398 & 2,297 & 2,185 \\
\hline Civil Departments: & 2,072 & 2,348 & 2,403 & 2,019 & 2,049 & 1,912 & 1,962 & 2,092 & 2,219 & 2,149 & 2,285 & 2,298 \\
\hline Indicative UK contributions to EU R\&D expenditure & 507 & 558 & 486 & 394 & 434 & 433 & 422 & 651 & 714 & 673 & 673 & 718 \\
\hline Ministry of Defence & 2,673 & 3,472 & 2,657 & 2,656 & 2,671 & 2,458 & 2,415 & 2,185 & 1,872 & 1,763 & 1,329 & 1,460 \\
\hline Research & 723 & 655 & 653 & 775 & 712 & 732 & 716 & 642 & 614 & 556 & 563 & 565 \\
\hline Development & 1,949 & 2,817 & 2,004 & 1,882 & 1,959 & 1,726 & 1,698 & 1,544 & 1,257 & 1,207 & 766 & 895 \\
\hline Total & 9,309 & 10,818 & 10,289 & 10,021 & 10,739 & 10,553 & 10,384 & 10,648 & 10,727 & 10,316 & 9,834 & 9,671 \\
\hline
\end{tabular}

Source: ONS, Science, engineering and technology statistics 2012, Tables 3 and 4 


\section{About the Library}

The House of Commons Library research service provides MPs and their staff with the impartial briefing and evidence base they need to do their work in scrutinising Government, proposing legislation, and supporting constituents.

As well as providing MPs with a confidential service we publish open briefing papers, which are available on the Parliament website.

Every effort is made to ensure that the information contained in these publically available research briefings is correct at the time of publication. Readers should be aware however that briefings are not necessarily updated or otherwise amended to reflect subsequent changes.

If you have any comments on our briefings please email papers@parliament.uk. Authors are available to discuss the content of this briefing only with Members and their staff.

If you have any general questions about the work of the House of Commons you can email hcinfo@parliament.uk.

\section{Disclaimer}

This information is provided to Members of Parliament in support of their parliamentary duties. It is a general briefing only and should not be relied on as a substitute for specific advice. The House of Commons or the author(s) shall not be liable for any errors or omissions, or for any loss or damage of any kind arising from its use, and may remove, vary or amend any information at any time without prior notice.

The House of Commons accepts no responsibility for any references or links to, or the content of, information maintained by third parties. This information is provided subject to the conditions of the Open Parliament Licence. 